\title{
PREDRAG CVETIČANIN
}

Centar za empirijske studije kulture jugoistočne Evrope, Niš

UDK: 316.7:061.2(497.11)"2009/2010"

316.7:061.2(497.16)"2009/2010"

316.7:061.2(497.7)"2009/2010"

\section{VANNSTITUCIONALNI} AKTERI KULTURNE POLLTIKEU SRBIII, CRNOJ GORI IMAKEDONIJ

Sažetak: U tekstu su prikazani rezultati istraživanja aktera kulturne politike koji deluju izvan sistema javnih/državnih kulturnih institucija u Srbiji, Crnoj Gori i Makedoniji (nevladinih organizacija koje se bave kulturom, nezavisnih kulturnih asocijacija, umetničkih udruženja, neformalnih umetničkih grupa, neprofitnih kulturnih klubova, itd.). Istraživanjem je obuhvaćeno ukupno 112 aktera nezavisne kulturne scene - u Srbiji 71, u Makedoniji 22 i u Crnoj Gori 19. Od obilja informacija dobijenih istraživanjem, u ovom tekstu smo se ograničili na to da u najkraćim crtama predstavimo rezultate istraživanja koji se tiču: a) karakteristika aktera nezavisne kulturne scene; b) uslova u kojima rade; c) saradnje aktera nezavisne kulturne scene sa nekoliko važnih grupa stakeholdera $i d$ ) da prikažemo osnovne rezultate merenja kapaciteta organizacija koje pripadaju nezavisnoj kulturnoj sceni u Srbiji, Crnoj Gori i Makedoniji. I da, s druge strane, ukažemo na neke od oblasti u kojima bi kreatori kulturne politike u ovim državama mogli da intervenišu, ukoliko žele da unaprede rad nezavisne kulturne scene u svojoj sredini.

Ključne reči: vaninstitucionalni akteri kulturne politike, kulturna politika

Ovaj tekst baziran je na podacima dobijenim u istraživanju koje je, u okviru istoimenog projekta, ${ }^{1}$ realizovano od oktobra 2009. do septembra 2010. godine.

1 Projekat „Vaninstitucionalni akteri kulturne politike u Srbiji, Crnoj Gori i Makedoniji“" realizovali su: Odbor za građansku inicijativu iz Niša, Nezavisna umetnička asocijacija „Remont“ iz Beograda, 
Projekat „Vaninstitucionalni akteri kulturne politike u Srbiji, Crnoj Gori i Makedoniji“ imao je tri osnovna cilja: a) da opiše i klasifikuje ključne aktere kulturne politike u ove tri države, koji deluju izvan sistema javnih/državnih kulturnih institucija (nevladine organizacija koje se bave kulturom, nezavisne kulturne asocijacije, umetnička udruženja, neformalne umetničke grupe, neprofitne kulturne klubove) i da izmeri kapacitete organizacija; b) da napravi mapu i proceni snagu nezavisne kulturne scene u ove tri zemlje u celini; ${ }^{2}$ i c) da otpočne proces operativnog/taktičkog umrežavanja vaninstitucionalnih aktera kulturne politke na nacionalnom i na regionalnom nivou, radi razmene kulturnih programa, zajedničkog konkurisanja kod međunarodnih fondera, jačanja kapaciteta nezavisne scene i povećanog uticaja na donosioce odluka u sferi kulturne politike na nacionalnom i lokalnom nivou.

U okviru projekta realizovane su u osnovi dve grupe aktivnosti: 1) istraživanje koje je uključivalo: a) anketno ispitivanje karakteristika organizacija koje pripadaju nezavisnoj kulturnoj sceni u Srbiji, Crnoj Gori i Makedoniji; b) polustrukturisane intervjue sa predstavnicima organizacija i inicijativa sa nezavisne scene u ovim zemljama; i c) polustrukturisane intervjue sa donosiocima odluka na nacionalnom i lokalnom nivou; i 2) seriju sastanaka i konferencija usmerenih na ispitivanje spremnosti aktera nezavisnih kulturnih scena ovih država za zajedničko delovanje i formiranje operativnih/taktičkih mreža na lokalnom, nacionalnom i regionalnom nivou.

U operacionalizaciji predmeta istraživanja - aktera kulturne politike koji deluju izvan sistema javnih-državnih kulturnih institucija ${ }^{3}$ - držali smo se sledećih kriterijuma: (a) da nisu osnovani od strane države, tj. da su ih članovi organizacija, grupa, inicijativa sami osnovali; (b) da samostalno definišu vlastitu organizacionu strukturu, procese odlučivanja i upravljanja; (c) da ne zavise finansijski

Centar za savremenu umetnost iz Skoplja i Centar za održivi prostorni razvoj „Expeditio“ iz Kotora uz finansijsku podršku Evropske kulturne fondacije i Ministarstva kulture Republike Srbije.

2 Zamišljeno je da mapa uključi i teritorijalni raspored vaininstitucionalnih aktera kulturne politike, ali da se u njoj prvenstveno nađu rezultati mapiranja bivših i postojećih članskih i operativnih mreža na ovim prostorima; mape trenutno aktivnih i već završenih zajedničkih projekata koje su realizovali akteri iz nezavisne kulturne scene ovih zemalja; i da se mapiraju odnosi aktera nezavisne kulturne scene sa oficijelnim kulturnim institucijama i donosiocima odluka na lokalnom i nacionalnom nivou.

3 U daljem tekstu sintagme ,,vaninstitucionalni akteri kulturne politike“ i ,akteri nezavisne kulturne scene“ će biti tretirani kao sinonimne. 


\section{PREDRAG CVETIČANIN}

i programski od države ili od nekog trećeg subjekta; ${ }^{4}$ (d) da je njihovo delovanje neprofitnog karaktera; ${ }^{5}$ i (e) da se bave prvenstveno savremenom umetnošću. ${ }^{6}$

Anketiranje je obavljeno u periodu od oktobra 2009. do februara 2010. godine. Korišćen je standardizovani upitnik sa 36 pitanja. Anketirane su ukupno 103 nezavisne organizacije, od toga 62 nezavisne organizacije u Srbiji, 19 u Crnoj Gori i 22 u Makedoniji. Pored toga, u periodu od oktobra 2009. do aprila 2010. godine urađena su i 102 intervjua sa predstavnicima vaninstitucionalnih aktera iz ciljnih država i to 70 u Srbiji, 17 u Makedoniji i 15 u Crnoj Gori. Pošto je jedan broj intervjua urađen sa predstavnicima neformalnih umetničkih grupa i nezavisnih kulturnih inicijativa (koji nisu anketirani), istraživanjem je obuhvaćeno ukupno 112 aktera nezavisne kulturne scene - u Srbiji 71, u Makedoniji 22 i u Crnoj Gori 19.

Kao što smo već pomenuli, u istraživanju smo koristili kombinaciju kvalitativnih i kvantitativnih metoda. $\mathrm{Na}$ jednoj strani koristili smo upitnik koji je bio prvenstveno namenjen merenju pet grupa kapaciteta anketiranih organizacija: ljudskih, tehničkih, finansijskih, menadžerskih i socijalnih. Na drugoj strani, upotrebljavali smo polustrukturisane intervjue za dobijanje podataka o saradnji na različitim nivoima (sa drugim akterima nezavisne scene, sa donatorima, donosiocima odluka, biznis zajednicom, medijima) i ocenu te saradnje; za uvide u najvažnije probleme sa kojima se vaninstitucionalni akteri kulturne politike suočavaju i puteve prevazilaženja tih problema; za mišljenje aktera nezavisne kulturne scene o daljim pravcima njenog razvoja u njihovoj zemlji i regionu. Unapred smo definisali 14 osnovnih tema razgovora grupisanih u tri celine: o organizaciji (misija organizacija, uslovima u kojima rade, problemi sa kojima se suočavaju, razvojni planovi organizacije); o saradnji koju imaju na različitim nivoima (unutar nezavisne kulturne scene, sa kulturnim institucijama, sa donosiocima odluka na nacionalnom i lokalnom nivou, sa biznis sektorom, međunarodna saradnja i članstvo u domaćim i međunarodnim kulturnim mrežama); i o nezavisnoj kulturnoj sceni u celini (osnovni problemi nezavisne kulturne scene i putevi

4 Ovi kriterijumi su preuzeti iz studije Emine Višnjić „Kulturne politike odozdo“" (2008).

5 Ovaj kriterijum je uveden da bi se akteri nezavisne kulturne scene razlikovali od privatnih menadžerskih agencija koji takođe deluju izvan sistema javnih kulturnih institucija.

6 Kriterijum da se bave privenstveno savremenom umetnošću omogućio nam je razlikovanje aktera nezavisne kulturne scene u ovim zemljama od organizacija koje se bave negovanjem kulturne baštine (poput recimo klapa u Crnoj Gori ili udruženja guslara u Srbiji).

7 Naša procena je da se radi o tri četvrtine ukupno aktivnih organizacija i inicijativa iz ove tri zemlje. 


\section{PREDRAG CVETIČANIN}

rešavanja tih problema; osnovni pravci razvoja nezavisne kulturne scene na nacionalnom i regionalnom nivou i mišljenje o mogućnostima i potrebi umrežavanja na nacionalnom i regionalnom nivou). Ispitanicima smo dozvoljavali i da uvode i nove teme u razgovor i podsticali ih da iznose svoje viđenje i ocene u odnosu na pitanja o kojima se razgovaralo.

Pored toga, tokom aprila i maja 2010. godine, obavili smo i osam intervjua sa predstavnicima uprava za kulturu Beograda, Novog Sada i Niša (u Srbiji); Ministarstva za kulturu Crne Gore i gradskih uprava za kulturu Podgorice i Kotora (u Crnoj Gori) i njihovih kolega u Skoplju i Bitolju (u Makedoniji). ${ }^{8} \mathrm{U}$ ovim intervjuima se razgovaralo o šest osnovnih tema: 1) da li postoji strategija odnosa Ministarstva kulture/gradske uprave prema nezavisnoj kulturnoj sceni i da li postoji neki dokument koji je definiše ili je ona implicitna; 2) da li ovi državni organi sistematski pomažu rad nezavisne kulturne scene (u celini, a ne samo pojedinih organizacija) i u čemu se ogleda podrška; da li postoje konkursi na kojima učestvuju predstavnici nezavisne kulturne scene/da li postoje konkursi rezervisani samo za organizacije koje pripadaju nezavisnoj kulturnoj sceni; 3 ) da li znaju za primere saradnje institucija kulture i vaninstitucionalnih aktera, i da li i na koji način način Ministarstvo kulture/gradska uprava podstiču ovu saradnju; 4) u čemu se, po njihovom mišljenju, ogleda glavni doprinos organizacija koje pripadaju nezavisnoj kulturnoj sceni, kulturnom životu u zemlji/u njihovom gradu; 5) koji su glavni problemi koje nezavisna kulturna scena ima u njihovoj zemlji/gradu (gledano iz ugla donosilaca odluka); i 6) kako oni vide budućnost

nezavisne kulturne scene u zemlji/njihovom gradu.

Triangulacijom podataka dobijenih na ove različite načine smatramo da smo uspeli da steknemo dosta dobar uvid u kapacitete organizacija koje čine nezavisnu kulturnu scenu, u uslove u kojima akteri deluju, probleme sa kojima se suočavaju, razvojne planove organizacija, različite forme saradnje koje ostvaruju (u okviru nezavisne kulturne scene, sa kulturnim ustanovama, sa biznis sektorom i sa međunarodnim donatorima), u kapacitete nezavisnih kulturnih scena kao celina i moguće pravce njihovog razvoja.

Naravno da ovo bogatstvo informacija nije moglo da uđe u tekst ovog obima. U njemu smo želeli da uradimo samo dve stvari. S jedne strane, da u najkraćim crtama predstavimo rezultate istraživanja koji se tiču: a) aktera nezavisne kulturne scene; b) uslova u kojima rade; c) saradnje aktera nezavisne kulturne scene sa nekoliko grupa važ-

8 U Srbiji i Makedoniji, uprkos pokušajima, nismo uspeli da organizujemo intervjue sa predstavnicima Ministarstva kulture ovih država. 


\section{PREDRAG CVETIČANIN}

nih stakeholdera i d) da prikažemo osnovne rezultate merenja njihovih kapaciteta. I da, s druge strane, ukažemo na neke od oblasti u kojima bi kreatori kulturne politike u ovim državama mogli da intervenišu, ukoliko žele da unaprede rad nezavisne kulturne scene u svojoj sredini.

\section{Akteri nezavisne kulturne scene}

Jedan od prvih utisaka koji se mogao steći ispitivanjem prikupljenog materijala jeste gotovo neverovatna šarenolikost aktera koji čine nezavisne kulturne scene u Srbiji, Crnoj Gori i Makedoniji. Mi smo pokušali da ih klasifikujemo u odnosu na dva aspekta: 1) imajući u vidu njihovu organizacionu formu i 2) prema njihovim odnosima sa institucionalnim (ne samo kulturnim) sistemom u ovim državama, tj. prema stepenu njihove samostalnosti/ nezavisnosti.

Među akterima nezavisne kulturne scene u Srbiji, Crnoj Gori i Makedoniji naišli smo na desetak različitih formi udruživanja. Među njima su najbrojnija a) udruženja građana (nevladine organizacije), ali smo takođe naišli na b) nezavisne umetničke asocijacije; c) kulturne fondacije; d) udruženja umetnika; ${ }^{9}$ e) neformalne umetničke grupe; f) neformalne umetničke grupe sa žiro računom; ${ }^{10}$ g) nezavisne kulturne inicijative; h) neprofitne kulturne klubove; i) kafe-klubove; j) neprofitne kulturne/koncerthe agencije; i k) neprofitne škole (glume, plesa, muzike) za decu i mlade. ${ }^{11}$

Na drugoj strani, i u odnosu na stepen njihove samostalnosti/nezavisnosti pojavile su se značajne razlike. Jedan od veoma čestih izvora nezadovoljstva među akterima nezavisne kulturne scene u sve tri države (a posebno u Makedoniji) odnosio se na postojanje „fantomskih“ udruženja građana u oblasti kulture. Ona se obično formiraju neposredno pred konkurse Ministarstva kulture i gradskih uprava za kulturu, na tim konkursima dobijaju ponekad i značajna sredstva, a potom samo formalno realizuju projekte ili ih čak uopšte ne realizuju i nestaju sa scene (i sa novcem). Među organizacijama koje smo mi anketirali/intervjuisali nije bilo takvih organizacija,

9 Registrovana kao udruženja građana.

10 Ove umetničke grupe su formalno registrovane kao udruženja građana, ali iz intervjua sa njima se moglo saznati da oni nemaju gotovo niti jednu karakteristiku organizacija (nemaju kancelarije, nemaju zajedničku opremu, nemaju formalno članstvo, ne održavaju sastanke, itd.). Njihovo objašnjenje za registrovanje udruženja je bilo da im je za njihove aktivnosti bio potreban žiro račun, da su, da ne bi stalno molili prijatelje, pristali na taj „birokratski“ okvir.

11 Posebno u Crnoj Gori. 
ali je broj prigovora i primera koje smo mogli čuti bio toliki, da nije bilo moguće ignorisati ovu pojavu. Neki od intervjuisanih aktera nezavisne kulturne scene su nam čak pomogli da napravimo klasifikaciju u odnosu na ovu dimenziju, prema kojoj bi na nezavisnoj kulturnoj sceni bilo moguće razlikovati (uključujući tu i različite vrste QuaNGOs): ${ }^{12}$ a) organizacije koje su u stvari produžene ruke državnih organa/političkih partija; b) organizacije koje predstavljaju ispostave kulturnih institucija, odnosno servis tih institucija za dobijanje sredstava iz fondova za koje inače ne bi mogli da konkurišu; c) organizacije koje su produžene ruke preko kojih međunarodne kompanije plasiraju svoja sredstva u organizaciju kulturnih događaja; d) organizacije koje su, u stvari, ogranci međunarodnih donatora; e) organizacije koje su formirali zaposleni u kulturnim institucijama koji su nezadovoljni radom svoje institucije (i kojima je delovanje u okviru nezavisne kulturne scene dopunska aktivnost); f) organizacije u kojima rade zaposleni izvan kulturnog sektora (na univerzitetima, u medijima, marketinškim agencijama, itd), a kojima je rad NVO koje se bave kulturom prilika da izraze taj deo svojih interesovanja; i g) organizacije čiji se članovi bave profesionalno radom u nezavisnom kulturnom sektoru i žive od toga.

Ova ogromna raznolikost unutar nezavisne kulturne scene (posebno kada se ove podele međusobno ukrste i kada im se doda i podela na organizacije i inicijative iz glavnih gradova i provincije) ${ }_{1}^{13}$ postaje ujedno objašnjenje atomizovnosti nezavisne kulturne scene u sve tri države. Razlike unutar nezavisne kulturne scene su toliko velike, da ih ujedinjava praktično jedino njihov sličan, neregulisan položaj ili, drugačije rečeno, da je njihov identitet definisan samo onime što one nisu (da nisu deo institucionalnog sektora). U toj meri su ekonomski i društveni statusi organizacija i zaposlenih u ovim organizacijama različiti da su i njihovi interesi različiti. To ujedno ostaje glavna prepreka njihovom udruživanju i umrežavanju.

Iz podataka dobijenih anketom moglo se videti da se među akterima nezavisne kulturne scene nalaze uglavnom male organizacije - u Srbiji i Makedoniji više od polovine ovih organizacija (57\%) ima manje od 10 članova, dok je u Crnoj Gori broj organizacija sa manje od 10 čla-

12 Kvazi-NVO-a

13 Među anketiranim organizacijama u Srbiji je bilo 35\% organizacija iz Beograda, 27\% organizacija iz Vojvodine, $20 \%$ organizacija iz južne i istočne Srbije i $17 \%$ organizacija iz centralne i zapadne Srbije. U Crnoj Gori je, od organizacija koje smo anketirali, polovina bila iz Podgorice, a ostali su bili sa jadranske obale (Kotor, Ulcinj, Tivat) i sa Cetinja. U Makedoniji je tri četvrtine anketiranih organizacija (17) bilo iz Skoplja, dve iz Bitolja i po jedna iz Tetova, Ohrida i Strumice. 


\section{PREDRAG CVETIČANIN}

nova veći od $80 \%$. U rad aktera nezavisne kulturne scene Srbije po našoj proceni uključeno je oko 1500 umetnika i menadžera u kulturi i otprilike još toliko volontera, dok je stalno zaposleno svega 60 ljudi. U Makedoniji, u nezavisnoj kulturnoj sceni deluje 250 umetnika i kulturnih menadžera i nešto malo veći broj volontera, dok je stalno zaposlenih ponovo svega 15. U Crnoj Gori, čija je nezavisna kulturna scena najnerazvijenija, radi 120 članova organizacija, oko 150 volontera i petoro stalno zaposlenih. Za razliku od političkih partija koje predstavljaju primer „muških“ organizacija i „ostatka“ nevladine scene u ovim državama koji predstavlja uglavnom ,ženski“ sektor, u nezavisnoj kulturnoj sceni u sve tri zemlje postoji rodni balans. ${ }^{14}$

Uprkos relativno malom broju angažovanih ljudi i veoma malom broju stalno zaposlenih, nezavisne kulturne scene u ovim zemljama organizuju godišnje veliki broj programa. U periodu od 2007. do 2009. godine nezavisna kulturna scena u Srbiji produkovala je između 1200 i 1500 programa godišnje (izložbi, performansa, koncerata, pozorišnih predstava, filmskih projekcija, umetničkih akcija). U Makedoniji je u ovom periodu taj broj bio između 400 i 700 programa, a u Crnoj Gori 50 do 70 programa godišnje. U ovome posebno važnu ulogu imaju neprofitni kulturni klubovi (poput Rex-a, Kulturnog centra „Grad“, CZKD, CK13 u Srbiji, Omladinskog kulturnog centra u Makedoniji ili Karvera/Prostory u Crnoj Gori) koji organizuju veliki broj programa (neki od njih organizuju i preko 100 programa godišnje).

Najveći broj organizacija/inicijativa koje smo anketirali bavi se organizovanjem kulturnih događaja: u Srbiji $63 \%$, u Makedoniji 57\%, a u Crnoj Gori 50\%, dok se isključivo produkcijom savremene umetnosti bavi u Makedoniji 23\%, Srbiji 29\%, a u Crnoj Gori 44\% organizacija. Imajući u vidu pojedinačne umetničke sfere, najveći broj organizacija/inicijativa iz Srbije i Makedonije deluje u oblasti vizuelnih umetnosti, dok je u Crnoj Gori, među anketiranima, najviše onih koji se bave muzikom i pozorištem. Ali je u sve tri zemlje, najviše organizacija/inicijativa koje deluju u više umetničkih sfera - u Srbiji 55\%, u Crnoj Gori 33\% i u Makedoniji 24\%.

14 Kada se u obzir uzmu samo organizacije koje su nam dale precizne podatke o svom članstvu, vidi se da npr. u Crnoj Gori među aktivnima u nezavisnoj kulturnoj sceni ima 53 muškarca i 63 žene, kao i da u rukovodstvima ovih organizacija ima 30 muškaraca i 36 žena. U Srbiji, slično ovome, u rad u nezavisnom kulturnom sektoru uključena 683 muškarca i 674 žene, a u rukovodstvima se nalazi 151 muškarac i 115 žena. U Makedoniji, u nezavisnoj kulturnoj sceni radi 116 muškaraca i 104 žene, dok se među članovima rukovodstava nalazi 46 muškaraca i 30 žena. 


\section{PREDRAG CVETIČANIN}

Među anketiranim organizacijama u Srbiji, dominiraju one sa godišnjim budžetom manjim od 10.000 EUR (u 2007. ih je bilo $38,5 \%$, u 2008. 33,9\%, a u 2009. godini $44,6 \%$ ). Broj organizacija sa godišnjim budžetom između 10.000 i 50.000 EUR smanjio se tokom posmatranog perioda od 40,4\% (2007) i 44,6\% (2008) na 28,6\% (2009). Dok je broj organizacija sa budžetom od preko 50.000 EUR ostao relativno stabilan tokom ovog perioda i čak se u 2009. godini donekle povećao: $21,2 \%$ (2007), 21,4\% (2008) i 26,8\% (2009). Specifičnost nezavisne kulturne scene u Makedoniji jeste da je većinski čine organizacije sa prosečnim godišnjim budžetom (između 10.000 i 50.000 EUR). U 2007. godini bilo ih je 52,6\%, u 2008. $57,8 \%$ i u 2009 . godini $45 \%$. Organizacije sa skromnim budžetom (manjim od 10.000 EUR) činile su 2007. godine $31,6 \%$, u 2008. 21,1\% i u 2009. godini 30\% ukupnog broja organizacija. Udeo organizacija sa budžetom preko 50.000 EUR u Makedoniji, bio je 15,8\% (2007), 21,1\% (2008) i 25\% (2009) U Crnoj Gori ogromna većina organizacija ima male godišnje budžete (ispod 10.000 EUR). U 2007. godini bilo ih je 83,3\%, u 2008, 76,9\% i u 2009 . godini $75 \%$. Prosečan godišnji budžet među organizacijama koje čine nezavisnu kulturnu scenu Crne Gore imalo je 16,7\% (2007), 15,4\% (2008) i 16,7\% (2009), dok su godišnje budžete preko 50.000 EUR imale samo dve organizacije. Iako se radi o vremenski kratkom periodu i o relativno malom broju organizacija i iz ovih podataka (vidi grafikone 1A, 1B i 1C) može se uočiti trend o kome se dosta moglo čuti tokom intervjuisanja članova organizacija koje pripadaju nezavisnoj kulturnoj sceni. Naime, da poslednjih godina dolazi do raslojavanja i da se scena „cepa“ na mali broj organizacija sa relativno velikim brojem članova, dobro opremljenih i sa velikim godišnjim budžetom (uglavnom u prestonicama ovih država) i na veliki broj malih organizacija koje pre predstavljaju grupe prijatelja (nego organizacije), koje organizuju aktivnosti iz privatnih stanova $\mathrm{i}$ čiji je godišnji budžet mali. A da se broj organizacija srednjeg obima (od kojih veliki broj radi u manjim gradovima) postepeno smanjuje. 
PREDRAG CVETIČANIN

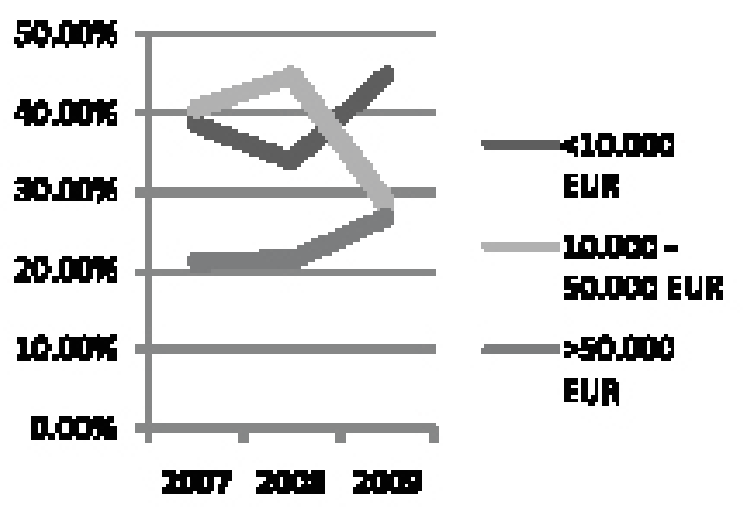

Grafikon $1 A$

Godišnji budžet organizacija u Srbiji (2007 - 2009)

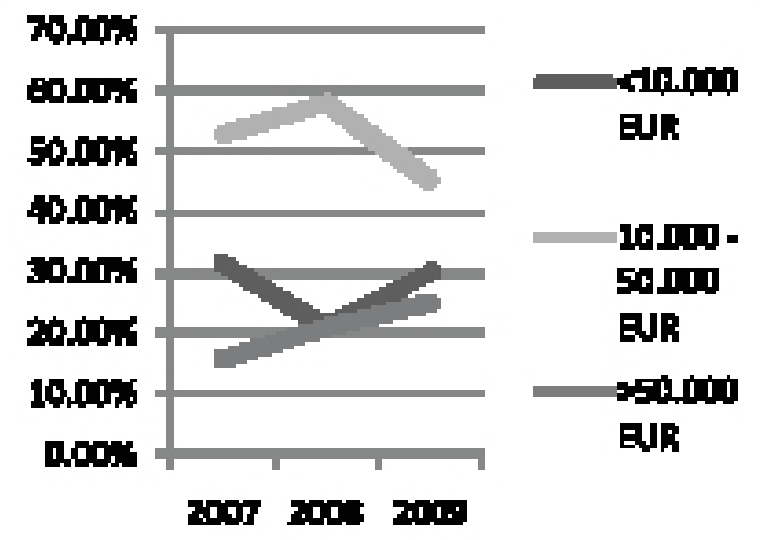

Grafikon $1 B$

Godišnji budžet organizacija u Makedoniji (2007 - 2009)

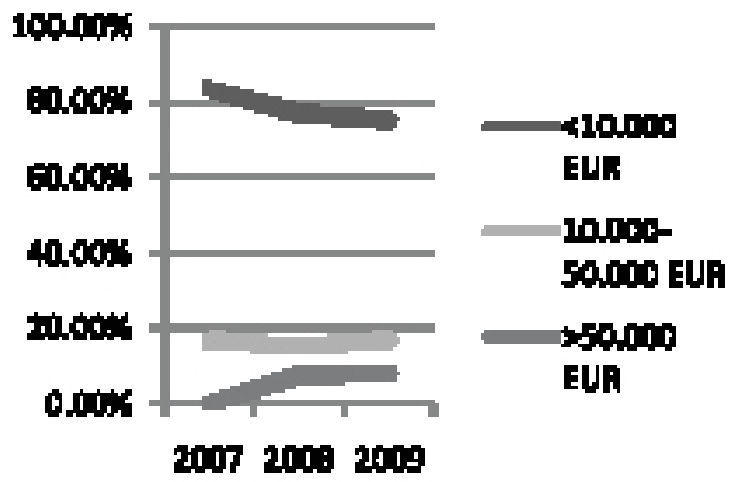

Grafikon $1 C$

Godišnji budžet organizacija u CrnojGori (2007 - 2009) 


\title{
PREDRAG CVETIČANIN
}

\section{Uslovi u kojima rade akteri nezavisne kulturne}

\author{
scene
}

Najveći broj intervjuisanih predstavnika nezavisne kulturne scene u sve tri države opisuje uslove za rad kao izuzetno loše. Osim malih i neizvesnih finansijskih sredstava, kao osnovni problemi navode se nedostatak prostora za rad, slaba opremljenost, nedovoljna zastupljenost u medijima, loša regulativa u oblasti kulture, ekstremna politizacija kulturne sfere (posebno u Srbiji), nerazumevanje sredine, uključujući tu i kolege iz ustanova kulture i donosioce odluka na lokalnom i nacionalnom nivou.

Nedostatak prostora za rad (i kancelarija i prostora u kojima bi se realizovali programi) predstavlja ključni problem nezavisne kulturne scene ${ }^{15}$ i ujedno domen u kome bi kreatori i realizatori kulturne politike u sve tri države mogli da učine najviše da pomognu njen razvoj. U Srbiji $40 \%$ organizacija nema kancelarije, a $60 \%$ nema prostorije za umetničke programe. U Makedoniji je situacija nešto bolja - nešto manje od $30 \%$ organizacija nema kancelariju, a oko 50\% nema mogućnost da programe realizuju u svom prostoru. U Crnoj Gori pak, samo tri organizacije imaju kancelariju, a samo jedna salu za programe. ${ }^{16}$

Podaci o opremi koju poseduju i koriste u radu, ponavljaju priču o „bogatoj“ i „siromašnoj“ braći. Kompjutere i štampače poseduje većina organizacija u Srbiji (više od $80 \%$ za kompjutere i više od $70 \%$ za štampače) i Makedoniji (više od $80 \%$ za oba), dok nerazvijenost nezavisne scene u Crnoj Gori pokazuje odsustvo čak i ove danas

15 Kako je rekla jedna od naših sagovornica u intervjuu: „Najveći problem nam je bio nedostatak prostora za rad, tako da smo od 2002. do 2007. godine radili po kafićima i kućama. To te gura u tu neku poziciju kao da ti to radiš iz hobija, iako je to, u stvari, tvoja životna misija - više od posla“.

16 Među onima koji su nam dali podatke, kancelarije veličine do $45 \mathrm{~m}^{2}$ u Srbiji ima 18 organizacija (oko 30\%), u Makedoniji devet organizacija (oko 25\%) i samo jedna organizacija u Crnoj Gori. Prostore između $46 \mathrm{~m}^{2}$ i $99 \mathrm{~m}^{2} \mathrm{u}$ Srbiji ima sedam organizacija (nešto više od 10\%), u Makedoniji dve organizacije i jedna organizacija u Crnoj Gori. A onih sa prostorima od $100 \mathrm{~m}^{2}$ i većim (za koje se utoliko može smatrati da rade u dobrim uslovima) ima šest u Srbiji i po jedna u Makedoniji i Crnoj Gori. Među ovim organizacijama, samo su dve organizacije u Srbiji i jedna u Crnoj Gori vlasnici prostora u kome rade, dok kancelarije i prostore za rad iznajmljuje 21 organizacija u Srbiji, devet organizacija u Makedoniji i dve organizacije u Crnoj Gori (prema podacima koje smo dobili, kirije za iznajmljivanje prostora kreću se u rasponu od 50 do 1000 EUR mesečno). Ono što ohrabruje jeste što je 12 organizacija u Srbiji i 6 organizacija u Makedoniji dobilo prostor za rad na korišćenje, pretpostavljamo od organa lokalnih samouprava. 


\section{PREDRAG CVETIČANIN}

elementarne opreme (koju poseduje samo jedna petina organizacija). Ali zato više od $70 \%$ organizacija u Srbiji i Makedoniji nema faks mašinu (u Crnoj Gori više od 90\% organizacija); 75\% organizacija u Srbiji nema mašinu za fotokopiranje (67\% u Makedoniji i 93\% u Crnoj Gori); $60 \%$ organizacija u Srbiji i Makedoniji i 85\% organizacija u Crnoj Gori nema video bim (LCD projektor). Samo pet organizacija u Srbiji ima službeni automobil, kao i dve organizacije u Makedoniji i jedna u Crnoj Gori. Četiri organizacije u Srbiji i tri organizacije u Makedoniji imaju binsku opremu, a razglas poseduje 12 organizacija u Srbiji, sedam u Makedoniji i jedna u Crnoj Gori. Ono što predstavlja problem, jeste da otprilike jedna petina organizacija u sve tri zemlje raspolaže svim resursima (i prostorom i kancelarijskom opremom i opremom za programe i voznim parkom), dok većina organizacija (osim kompjutera, štampača i možda internet veze) ne poseduje ništa više.

Tri karakteristike konteksta delovanja vaninstitucionalnih aktera kulturne politike u Srbiji, Crnoj Gori i Makedoniji koje su u intervjuima najčešće pominjane jesu: politizacija kulturne sfere, njena normativna neregulisanost i nestabilnost.

Većina intervjuisanih pominje ekstremnu politizaciju kulturne sfere kao jednu od osnovnih prepreka za vlastiti razvoj. Ocena je da ,raspodela“ kulturnih ustanova (i čitavih umetničkih sfera) na osnovu koalicionih dogovora, političko postavljanje direktora i političko zapošljavanje ne uništavaju samo institucionalnu sferu kulture u Srbiji, Crnoj Gori i Makedoniji, nego se uspostavljaju kao dominantni način delovanja u kulturnom polju (i degenerišu i sve drugo u njoj). I da samim tim politički kanali postaju jedini način rešavanja problema na nezavisnoj kulturnoj sceni (u formi „predaje“, „prodaje“ ili „,protesta“). 


\section{PREDRAG CVETIČANIN}

Prigovori koji su se odnosili na lošu normativnu uređenost kulturne sfere kod većine sagovornika u intervjuima nisu se ticali toliko rešenja prisutnih u tekstu zakona, ${ }^{17}$ koliko odsustva njihove primene u praksi. Prigovori su se odnosili i na nepostojanje strategije kulturnog razvoja na državnom, pokrajinskom i gradskom nivou, na jako velika diskreciona prava donosilaca odluka (ministra za kulturu, gradskih sekretara za kulturu), kao i na činjenicu da se u najvećem broju slučajeva ne zna ko vrši donošenje odluka i na osnovu kojih kriterijuma. ${ }^{18}$ I naravno, posebno su žestoke primedbe na odsustvo bilo kakvog uticaja aktera nezavisne kulturne scene na kreiranje kulturnih politika u ovim državama, pa čak ni u onom segmentu

koji se nezavisne kulturne scene neposredno tiče. ${ }^{19}$

Poslednja karakteristika konteksta delovanja vaninstitucionalnih aktera o kojoj se često govorilo u intervjuima jeste izuzetna nestabilnost društava u regionu. To naravno nije okolnost koja otežava samo aktivnosti nezavisne kulturne scene, ali ih njihova „ranjivost“" (u pogledu stabilnosti finansiranja, prostora za rad, mogućnosti da na duži period angažuju saradnike) čini posebno osetljivim u odnosu na društvene turbulencije. ${ }^{20}$

17 U Srbiji delovanje udruženja građana u kulturi regulišu Zakon o kulturi (2009) i Zakon o udruženjima građana (2009). U Crnoj Gori tu ulogu imaju Zakon o nevladinim organizacijama (2007) i Zakon o kulturi (2008). U Makedoniji je na snazi Zakon o kulturi iz 1998. godine (donekle izmenjen i dopunjen amandmanima 2003. godine) i Zakon o udruženjima i fondacijama (iz 2010. godine).

18 Česte kritike su se odnosile na to što na konkursima Ministarstva kulture nema obrazloženja odluka, niti pak nakon realizacije projekata, njihove evaluacije: „,Mora da se radi ono što su rekli da im je skupo i dosadno: da rade evaluaciju realizacije projekata. Dok oni nemaju uvid u to, za one kojima su dali pare, šta je on s tim parama uradio - biće ovako kako je sada. Zato mi ne možemo da steknemo nikakav kredit kod njih - iako radiš vredno i pošteno i podnosiš izveštaje i realizuješ projekte. Zato je svejedno, da li si ti pobegao s parama na more ili si uradio pet puta više nego što si rekao, jer ne postoji monitoring i ne postoji evaluacija u kojoj će to da se vidi. Zato je moguće da ti sledeće godine ne dobiješ ništa, kao ni onaj koji je pobegao na more".

19 „Nezavisna kulturna scena apsolutno ne učestvuje u kreiranju kulturne politike, čak ni u onom segmentu koji se bavi nezavisnom scenom. To je taj glavni apsurd o kome ja stalno, kad mi daju prostora, govorim. Prosto je to neshvatljivo“. Ili „Pripadamo tzv. „,trećem sektoru" koji zapravo nema učešća u kreiranju same kulturne politike, nego je potpuno marginalizovan i zavisi od dobre volje jednog pojedinca unutar određene političke partije koja je na vlasti... znači njegovog ličnog afiniteta prema stvarima koje se događaju u trećem sektoru".

20 U odgovoru na naše pitanje o tome kako vidi budućnost nezavisne kulturne scene u Srbiji, jedan naš sagovornik je rekao: „, Kad bih znao kako će ova zemlja da izgleda za nekoliko godina, znao bih $i$ kako će scena da izgleda“. 


\section{PREDRAG CVETIČANIN}

Još jedan problem na koji su intervjuisani često ukazivali jeste nerazumevanje sredine vezano i za to što rade (inovativne kulturne programe), ali posebno u odnosu na prirodu njihovih organizacija i delovanja. To je ono što na jednoj strani dovodi do nedovoljne zastupljenosti u lokalnim i nacionalnim medijima. Ali još i važnije, u kontaktima s donosiocima odluka i sa potencijalnim donatorima, akteri nezavisne scene susreću se sa nerazumevanjem da se ne radi o privatnim organizacijama, nego o organizacijama koje služe javnom interesu. ${ }^{21}$

\section{Saradnja}

U našem istraživanju ispitivali smo i saradnju organizacija i inicijativa koje pripadaju nezavisnoj kulturnoj sceni sa četiri grupe važnih zainteresovanih aktera (stakeholdera): a) sa drugim predstavnicima nezavisne kulturne scene (u gradu, zemlji i inostranstvu); b) sa institucijama

kulture; c) sa donatorima; i d) sa biznis sektorom.

U odgovorima na pitanja iz ankete koja su se ticala saradnje sa drugim predstavnicima nezavisne kulturne scene, ispitanici su potvrdili postojanje saradnje na nivou gradova (72\% u Srbiji, 50\% u Crnoj Gori i 48\% u Makedoniji) i unutar zemlje (58\% u Srbiji, 38\% u Makedoniji i 21\% u Crnoj Gori). Međutim, u intervjuima se moglo čuti da je saradnja unutar nezavisne kulturne scene, tamo gde postoji, ustvari „saradnja sa drugarima“ - ad hoc i lična i bazirana na rešavanju tekućih problema (oko opreme, oko prostora, itd). Tamo gde postoje trajniji oblici saradnje, ona se do sada ostvarivala samo na programskom nivou, a nije bilo saradnje u pravnom i političkom polju - vezane za zaštitu interesa onih koji rade u nezavisnoj kulturnoj sceni. ${ }^{22}$ Ono što se $\mathrm{u}$ intervjuima takođe moglo čuti (u sve tri sredine) jesu žalbe na nedostatak solidarnosti unutar nezavisne kulturne scene i dominaciju borbi ličnih sujeta, posebno rukovodilaca organizacija. A već

${ }^{21}$ Kako je to izrazila jedna naša sagovornica: „Problem je što ljudi ne razumeju šta to znači kada si nezavisna organizacija. Ljudi misle, s obzirom da nas nije formirao grad, da je to naša privatna stvar. Privatna stvar, privatno pozorište, privatne pare, u stvari ne shvataju da je to jedan novi model organizovanja koji može da sarađuje i sa zvaničnim institucijama i sa nevladinim sektorom. To je veliki problem u glavama ljudi - kako bi to moglo da bude pomognuto $i$ finansirano..."

$22 U$ istraživanju smo zabeležili i četiri pokušaja formiranja mreža, od kojih tri na lokalnom nivou u Srbiji (pozorišna mreža „ANET“ u Beogradu, mreža organizacija, grupa i pojedinaca iz Beograda „Druga scena“ i platforma „Za kulturne politike“ iz Novog Sada) i pokušaj formiranja nacionalne mreže u Makedoniji. 


\section{PREDRAG CVETIČANIN}

smo ukazali da iza podeljenosti nezavisnih scena u ove tri države, leže i objektivno različiti interesi organizacija koje ih čine.

Što se međunarodne saradnje tiče, polovina organizacija u Srbiji, skoro $60 \%$ organizacija iz Crne Gore i skoro $70 \%$ organizacija iz Makedonije realizovalo je ili realizuje zajedničke projekte sa partnerima iz inostranstva. ${ }^{23}$ Među partnerima organizacija iz Srbije najviše je onih iz bivših jugoslovenskih republika (37), posebno iz Bosne i Hercegovine i Hrvatske (po sedam). Potom slede partneri iz Zapadne Evrope (16) ${ }^{24}$ i Istočne Evrope (pet), dok sa partnerskim organizacijama izvan Evrope (SAD) sarađuje samo jedna organizacija. Najveći broj partnera makedonskih organizacija dolazi iz zapadne Evrope (20), ${ }^{25}$ dok organizacije iz Makedonije sarađuju sa 14 partnera iz bivših jugoslovenskih republika, četiri partnera iz istočne Evrope i jednim partnerom iz SAD. Broj međunarodnih partnera crnogorskih organizacija je najmanji. One, slično organizacijama iz Srbije, partnere najčešće nalaze na bivšem jugoslovenskom prostoru (6). Partneri iz Zapadne Evrope imaju četiri organizacije, da bi saradnja sa organizacijama iz Istočne Evrope bila svedena na jednu partnersku organizaciju iz Albanije, a ona izvan Evrope na jednu američku organizaciju.

Saradnja organizacija i inicijativa iz nezavisne kulturne scene sa javnim kulturnim ustanovama predstavlja još jedno polje kojim bi kreatori kulturne politike u ovim državama trebalo da se pozabave. Granica između javnih kulturnih institucija i organizacija koje dolaze sa nezavisne scene u zemljama sa razvijenim kulturnim sistemima danas gotovo da i ne postoji, ali je ona u tri zemlje u kojima smo radili istraživanje izuzetno rigidna. Ona čak u izvesnom smislu predstavlja ,granicu“ do koje državni organi vode kulturnu politiku, tako da se nezavisna kulturna scena u njima često pojavljuje, ne kao nešto što je izvan institucionalnog kulturnog sistema, nego nešto što se tretira kao da je izvan sistema kulturne politike. Sve mere koje u ovom tekstu (i u studiji koja će se uskoro pojaviti) zagovaraju, u stvari i nisu ništa drugo do predlaganje različitih formi kroz koje bi nezavisni kulturni sektor sistematski i realno (a ne, kao do sada, samo deklarativno) bio uveden u domen kulturne politike kojim

23 Zanimljivo je da, bar sudeći prema ovim rezultatima, organizacije iz Crne Gore i Makedonije, češće sarađuju sa partnerskim organizacijama iz inostranstva, nego sa svojim kolegama u zemlji.

24 Po tri partnerske organizacije iz Francuske, Nemačke, Švajcarske i Belgije i po jedna iz Holandije, Italije, Norveške i Austrije.

25 Najviše partnerskih organizacija akteri nezavisne scene u Makedoniji imaju u Nemačkoj (osam), a potom u Francuskoj (pet) i u Holandiji (tri). 


\section{PREDRAG CVETIČANIN}

se aktivno bave ministarstva kulture, gradske uprave za kulturu i druga državna tela u ovim zemljama. Imajući u vidu rezultate istraživanja, naše je uverenje da to ne bi samo nezavisnoj kulturnoj sceni obezbedilo opstanak i napredovanje u ovim državama, nego bi obogatilo kulturnu sferu u njima u celini.

Prema podacima iz anketa, velika većina aktera nezavisne kulturne scene već sarađuje sa javnim kulturnim ustanovama: u Srbiji skoro 90\%, a u Crnoj Gori i Makedoniji oko $80 \%$, ali se pod saradnjom uglavnom podrazumeva povremeno korišćenje prostora kulturnih institucija za vlastite programe. Ono oko čega se većina predstavnika vaninstitucionalnih aktera slaže jeste da saradnja sa institucijama kulture presudno zavisi od ličnosti koje vode ove institucije - i da je utoliko ona lična, a ne institucionalna. To se najbolje može videti po tome što, dosta često, smena direktora neke ustanove, znači i prekid (ili uspostavljanje) saradnje sa nezavisnom kulturnom scenom. Zamoljeni da prokomentarišu značaj saradnje sa javnim kulturnim ustanovama za nezavisnu kulturnu scenu, jedan broj intervjuisanih je zastupao stav da je saradnja sa institucijama kulture dobra za aktere iz nezavisne kulturne scene, jer se kroz nju postiže vidljivost vaninstitucionalnih aktera u kulturi. Na drugoj strani postoje i oni koji imaju suprotan stav i smatraju da je saradnja između aktera nezavisne kulturne scene i državnih institucija kulture nakaradna, i da se kroz ovu saradnju akteri nezavisne scene koriste za promociju političkih stranaka koje vode kulturu u gradu, odnosno onih koje su postavile direktore $\mathrm{u}$ te kulturne ustanove.

Onima koji se teorijski bave kulturnom politikom, jasno je da bi saradnja između javnih kulturnih ustanova $i$ aktera sa nezavisne kulturne scene $u$ našem regionu bila pravi primer situacije u kojoj svi dobijaju (a posebno publika u ovim gradovima). Resursi kojima kulturne institucije i vaninstitucionalni akteri raspolažu su kom- 
plementarni: kulturne institucije imaju prostore i opremu (koji vaninstitucionalnim akterima nedostaju) i među njihovim kadrovima ima dobro obrazovanih stručnjaka (dobrih kustosa, istoričara umetnosti, muzikologa, itd.). Ali je ljudima iz kulturnih ustanova najčešće stran fleksibilan pristup menadžmentu koji je neophodan $\mathrm{u}$,turbulentnim okolnostima“" kakve postoje u našem regionu; i nepoznat im je čitav spektar veština neophodnih za delovanje u kulturnoj sferi u savremenim uslovima: pisanja predloga projekata, menadžmenta projekata, monitoringa i evaluacije, strateškog planiranja, zagovaranja - kojima aktivisti nevladinih organizacija vladaju. ${ }^{26}$ Predrasude postoje na obe strane, ${ }^{27}$ ali bi neposredne i posredne mere kulturne politike od strane državnih organa, pored već postojećih mera međunarodnih donatora, mogle pomoći da se ovaj

jaz premosti.

Jedno od iznenađenja koje je donelo istraživanje jeste da mnogo manji broj organizacija koje pripadaju nezavisnoj kulturnoj sceni konkuriše kod međunarodnih donatora za realizaciju projekata i zavisi od sredstava iz inostranstva, nego što smo mi to mislili. Za $70 \%$ organizacija u Srbiji i $60 \%$ organizacija u Makedoniji, manje od polovine njihovog budžeta dolazi iz fondova međunarodnih donatora. U Crnoj Gori, u budžetima čak tri četvrtine organizacija manje od $20 \%$ potiče od inostranih fondacija.

Među donatorima pomenutim u anketi, u sve tri zemlje pojavljuju se uglavnom ista međunarodna tela i organizacije aktivni u ovom regionu: Evropska komisija, USAID, Švajcarski kulturni program na zapadnom Balkanu (SCP), Evropska kulturna fondacija (ECF), Fond za otvoreno društvo (u Srbiji, Crnoj Gori i Makedoniji), KulturKontakt iz Austrije; Schüler Helfen Leben (SHL) iz Nemačke, Ekumenska inicijativa žena, Global Fund for Women; Švedska međunarodna agencija za razvoj (SIDA), Nordic Fund, UNESCO i UNDP. Ono što je specifično za Makedoniju jeste nešto aktivnija uloga ambasada (Ne-

26 Jedna od sagovornica u intervjuu je ovo sažela na sledeći način: „Mi se u stvari nudimo. Pošto smatramo da imamo odlične ljudske resurse, odlično iskustvo i da kada se pogleda da smo bili po celom svetu i obrazovali u mnoštvu različitih oblasti... To je jedan tako ogroman potencijal, tako da smatramo logičnim da nas država iskoristi za sopstveni razvoj. Eto, nama je cilj da nas se iskoristi za razvoj ".

27 Akteri nezavisne kulturne scene često ne razumeju mehanizme i procedure na osnovu kojih zaposleni u kulturnim ustanovama deluju, te ih izjednačavaju za „,birokratama“ i „službenicima“, koji nemaju sluha za kreativno delovanje. Na drugoj strani, menadžeri iz kulturnih ustanova često aktere nezavisne scene posmatraju kao „diletante“, ,amatere“ i sl. Predrasudama doprinose i ,legende“ o ogromnim finansijskim sredstavima koje stižu iz inostranstva na žiro račune nevladinih organizacija u kulturi, za razliku od kulturnih ustanova koje rade u uslovima krajnje oskudice. 


\section{PREDRAG CVETIČANIN}

mačke, SAD, Holandije, Poljske) u finansiranju aktivnosti nezavisne kulturne scene. U Srbiji, specifičnost donatorske scene čini jedan broj međunarodnih kompanija koje deluju u zemlji i čija poslovna filozofija uključuje podršku inovativnim kulturnim i umetničkim aktivnostima (poput npr. kompanije Telenor, ili Erste banke i Societe Generale banke).

Većina intervjuisanih predstavnika vaninstitucionalnih aktera je pohvalila saradnju sa inostranim donatorima, zato što je predvidljiva - da se odvija prema pravilima, koja su doduše ponekad rigidna, ali su bar jasna i kojih se donatori drže. U jednom broju intervjua, saradnja sa međunarodnim donatorima je ocenjena dobrom, zbog toga što donatori ne nameću i ne zahtevaju menjanje projekata, već podržavaju projekte koje akteri iz nevladine kulturne scene sami formulišu (iako uglavnom podržavaju one koji se uklapaju u njihove ciljeve i prioritete). Međutim, bilo je i onih koji su tvrdili da su neki od donatora zahtevali promociju određenih vrednosti i praksi, da bi finansirali njihove aktivnosti. Dve zamerke koje su se češće mogle čuti, bile su vezane za praksu donatora da kopiraju gotove modele iz njihovih država (ili iz regiona gde su prethodno radili), bez pokušaja da upoznaju lokalnu situaciju, što je povremeno dovodilo do potpuno pogrešnih politika u odnosu na ono što se zbiva na terenu. I drugo, što je posebno za grupe umetnika bilo neprihvatljivo, bile su komplikovane procedure prijavljivanja i izveštavanja o projektima, što je vodilo tome da su, po njihovim rečima, više vremena provodili popunjavajući aplikacione forme i izveštaje, nego baveći se konkretnim kulturnim/umetničkim aktivnostima.

Razvoj saradnje sa biznis sektorom je često jedan od preporučenih puteva za jačanje nezavisne kulturne scene. Rezultati anketa pokazuju da otprilike $60 \%$ organizacija u Srbiji, 40\% u Makedoniji i 30\% organizacija u Crnoj Gori ima iskustva u saradnji sa privatnim kompanijama i negde oko trećine anketiranih organizacija - u sve tri države - u saradnji sa državnim preduzećima. Detaljniji opis ove saradnje u intervjuima ukazuje, međutim, da se saradnja (u oba slučaja) odvija gotovo isključivo pre- 
ko prijateljskih veza i da je pomoć koja se dobija ili inkind (u obliku robe i usluga) ili da se radi o minimalnim novčanim iznosima. Razlozi koji se $u$ intervjuima navode za nizak nivo pomoći uglavnom se tiču toga da biznis sektor objektivno nema interesa da pomaže rad nezavisne kulturne scene, a da nema zakonske regulative koja bi tu saradnju podstakla. ${ }^{28} \mathrm{U}$ intervjuima se mogla čuti i procena da su vrednosti za koje se zalaže nezavisna kulturna scena direktno suprotne vrednostima novog biznis sektora (novokomponovanih vlasnika) u regionu, te da je menadžerski sloj u međunarodnim kompanijama spreman da pomogne, ali je vlasnički sloj u domaćim kompanijama potpuno nezainteresovan. Jedan broj anketiranih zastupao je stanovište da je to oblast saradnje koji ima šanse da se razvije i da na njemu treba raditi, te da bi se u dogledno vreme mogla desiti promena u odnosu na atmosferu vezanu za fondove i zadužbinarstvo (u či-

tavom regionu).

Ono što je zanimljivo primetiti jeste da je u svim posmatranim domenima saradnje, ${ }^{29}$ ona personalizovana, to jest da zavisi od ličnih veza i poznanstava sa partnerima. Verovatno da bi institucionalizacija ove saradnje trebalo da predstavlja važan korak i u promenjenoj strategiji nezavisne kulturne scene i u budućem ponašanju kreatora kulturne politike, kulturnih ustanova i predstavnika poslovne zajednice.

\section{Rezultati merenja kapaciteta}

Kao što smo već pomenuli, upitnik koji smo koristili bio je prvenstveno namenjen merenju pet grupa kapaciteta anketiranih organizacija: ljudskih, tehničkih, finansijskih, menadžerskih i socijalnih. On je formulisan imajući u vidu standardne metode za procenu kapaciteta organizacija kao što su Participatory Result-Oriented Self-Evaluation (PROSE), Institutional Development Framework (IDF), Organizational Capacity Assesment Tool (OCAT), WWF Organizational Assesment Tool and Organizatio-

28 Još jedna od poželjnih indirektnih mera kulturne politike bilo bi uvođenje značajnijih poreskih olakšica za one članove poslovne zajednice spremne da ulažu u kulturu (i da pomognu delovanje nezavisne kulturne scene). Prethodni korak bi bio prevođenje organizacija iz nezavisne kulturne scene u sve tri države iz neodređenog statusa „ostalih organizacija na bazi učlanjenja“ (kako god to bilo formulisano) u status udruženja građana koja se bave kulturom.

29 Izuzev možda u odnosima sa donatorima, mada bi detaljnije istraživanje ovih odnosa, verovatno ukazivalo na značaj socijalnih mreža poznanstava u dugoročnom finansiranju određenih organizacija i pravovremene dostupnosti korisnih informacija. 
nal Capacity Indicator (OCI). ${ }^{30} \mathrm{Na}$ osnovu indikatora razvijenosti kapaciteta u analizi su konstruisane skale za svaki od tipova resursa, da bi potom kapaciteti organizacija bili mereni u odnosu na te skale. Za merenje ukupne razvijenosti kapaciteta organizacija koristili smo klaster analizu (metodu „najbližeg suseda“) koja je u svakoj od ciljnih zemalja izdvajala nekoliko klastera prema stepenu izgrađenosti njihovih kapaciteta.

Što se tiče ljudskih resursa, skalu smo konstruisali kombinujući dve dimenzije. Jedna grupa pitanja ticala se ukupnog broja članova organizacije, broja zaposlenih, volontera, to jest toga koliko ljudi mogu da angažuju u svojim aktivnostima. Druga grupa pitanja ticala se obrazovnog profila članstva - procenta članova sa određenim nivoom obrazovanja i toga koliko članova organizacije vlada veštinama neophodnim za rad u nevladinom sektoru - pisanjem predloga projekata, pisanjem završnih izveštaja donatorima i elementarnim računovodstvenim operacijama. Ova druga dimenzija je merila stepen njihove osposobljenosti za delovanje. Na osnovu ovih dimenzija konstruisana je skala čiji je maksimum bio 27 poena, da bi se potom ona koristila kao instrument za merenje stepena razvijenosti ljudskih resursa u organizacijama uključenim $u$ istraživanje.

Već smo pomenuli da uprkos relativno malom broju angažovanih ljudi i veoma malom broju stalno zaposlenih, nezavisne kulturne scene u ovim zemljama organizuju godišnje veliki broj programa. To je omogućeno time što su ljudski resursi - ključni resursi nezavisne kulturne scene. U organizacijama u sve tri države u preko $80 \%$ organizacija dominiraju članovi sa fakultetskim i višim obrazovanjem. U Makedoniji u 76\% organizacija najveći broj članova ima završen fakultet, a još u $14 \%$ organizacija ima najviše članova sa magistraturom i doktoratom. U Srbiji u $72 \%$ organizacija dominiraju članovi sa završenim fakultetom, dok još u 17\% najviše članova ima titule magistra i doktora nauka. Slično tome, u Crnoj Gori u 78\% organizacija većina članstva ima završen fakultet, dok u jednoj ima najviše onih sa magistraturom i dokto-

30 O ovim metodama vidi više u Cvetičanin, $\mathrm{P}$ „Merenje kapaciteta nevladinih organizacija iz južne i istočne Srbije“, OGI, Niš, 2005. godine. Ostale metode koje bi trebalo pomenuti jesu ISR (Institutional Self-Reliance) koji je razvijen za UNDP; TTAP (Training and Technical Assistance Plan) razvijen za Counterpart International; ISA (Institutional Strength Assessment) stvoren u okviru Child Survival Technical Support (CSTS) projekta; From the Roots Up (World Neighbors) i dr. O ovim i drugim metodama procene kapaciteta organizacija moguće je informisati se i na web stranicama: www.nacvs.org.uk, www.ncvo-vol.org.uk, www.dec.org/usaid_eval, www.skillup.org, www.impactalliance.org/ev.php, www. mande.co.uk/specialist.htm. 
ratom. Ali i mimo formalnog obrazovanja, članovi organizacija koje pripadaju nezavisnoj kulturnoj sceni vladaju veštinama pisanja predloga projekata, menadžmenta projekata, zagovaranja, finansijskog menadžmenta, pisanja izveštaja donatorima, itd. To organizacije nezavisne kulturne scene čini verovatno najobrazovanijim organizacijama/grupama u kulturnom polju u Srbiji, Crnoj Gori i Makedoniji.

Pitanja o tehničkim resursima odnosila su se na uslove za rad i opremu kojima nevladine organizacije raspolažu: najpre, veličine i prilagođenosti kancelarijskih prostora; da li imaju prostor za umetničke aktivnosti ili ne; da li su vlasnici prostorija u kojima rade ili ih iznajmljuju i od koga. A drugi set pitanja se ticao opreme i to tri grupe: 1) kancelarijske opreme (kompjutera, printera, skenera, modema, telefona, faks-mašina, fotokopir mašina), 2) opreme za umetničke programe: (ozvučenje, binska oprema, svetlosni park, foto-video-TV oprema, LCD projektor, itd.) i 3) voznog parka (automobila, kombija, kamiona).

Konstruisana skala imala je maksimum od 24 poena.

U Makedoniji je jako dobre tehničke resurse imalo skoro $40 \%$ organizacija, u Srbiji 25\% organizacija, a u Crnoj Gori ponovo dve organizacije. Na drugoj strani tehničke resurse koji su slabi imalo je oko $20 \%$ organizacija u Srbiji i Makedoniji, i čak 70\% organizacija u Crnoj Gori.

$\mathrm{U}$ istraživanju je ispitivano nekoliko tipova menadžerskih kapaciteta organizacija: jedna grupa pitanja se odnosila na oblast strateškog menadžmenta (strateško planiranje, definisanost i poznavanje misije organizacije, usklađenost projektnih aktivnosti sa misijom organizacija); druga grupa pitanja koja se odnosila na menadžment ljudskih resursa (mehanizmi za odlučivanje u NVO, podela poslova u NVO i nivo obaveštenosti članstva), dok se treća grupa pitanja ticala finansijskog menadžmenta (redovnost analiza finansijskog poslovanja, angažovanje profesionalnih računovođa). Ukrštanjem ovih dimenzija dobijena je skala čiji je maksimum bio 16 poena.

U Srbiji je samo 5 organizacija (8\%) imalo jako dobro razvijene menadžerske resurse, u Crnoj Gori samo jedna (7\%), dok u Makedoniji nije bilo organizacija sa jako dobro razvijenim menadžerskim resursima. Locirane nešto niže na skali, dobro razvijene menadžerske resurse imalo je $40 \%$ organizacija u Makedoniji, 20\% organizacija u Srbiji i 35\% organizacija u Crnoj Gori. A nerazvijene resurse u ovom domenu je imalo skoro $40 \%$ organizacija u Makedoniji i Crnoj Gori i nešto više od 20\% organizacija u Srbiji.

Finansijski kapaciteti organizacija ispitivani su kroz podatke o veličini i izvorima budžeta (pojedinci, privatne 
kompanije, državna preduzeća, organi lokalne samouprave, ministarstva kulture, domaće fondacije, inostrane fondacije, vlastiti izvori), diverzifikaciji izvora finansiranja i nivou prihoda zaposlenih. Maksimum na konstruisanoj skali bio je 13 poena.

Analiza je pokazala da jako dobre finansijske kapacitete ima desetak organizacija u Srbiji (15\%), dve organizacije u Makedoniji (10\%), a da u Crnoj Gori nema takvih organizacija. U Crnoj Gori dve organizacije raspolažu dobro razvijenim finansijskim resursima (14\%), dok slabe finansijske kapacitete ima skoro polovina organizacija. U Srbiji dobro razvijene finansijske kapacitete ima $35 \%$ organizacija, dok su u $20 \%$ organizacija finansijski kapaciteti nedovoljno razvijeni. I na kraju, u Makedoniji, dobro razvijene finansijske kapacitete ima više od polovine organizacija, dok su, slično kao u Srbiji, ovi kapaciteti kod jedne petine organizacija nerazvijeni.

Procena razvijenosti socijalnih resursa, to jest odnosa organizacija nezavisne kulturne scene sa njihovim socijalnim okruženjem, bazirala se na oceni saradnje sa drugim pripadnicima nezavisne kulturne scene u gradu u kome deluju, iz zemlje i iz inostranstva, saradnje sa kulturnim institucijama, saradnje sa privatnim i državnim kompanijama, medijima i donatorima. Maksimum na konstruisanoj skali je bio 26 poena.

Ako su ljudski resursi najbolji deo nezavisne kulturne scene u ciljnim zemljama, onda je istraživanje pokazalo da su njihovi menadžerski i socijalni resursi (shvaćeni kao odnosi aktera nezavisne kulturne scene sa drugim važnim akterima u njihovom socijalnom okruženju) njen najslabiji deo. U Srbiji i Makedoniji samo 10\% organizacija ima jako dobro razvijene socijalne resurse, a u Crnoj Gori samo jedna organizacija. Na drugoj strani socijalni resursi $20 \%$ organizacija u Srbiji, skoro 30\% organizacija u Makedoniji i skoro $40 \%$ organizacija su potpuno nerazvijeni.

Generalno, ispitivanje pet tipova kapaciteta vaninstucionalnih aktera u Srbiji, Crnoj Gori i Makedoniji (ljudskih, tehničkih, finansijskih, menadžerskih i socijalnih) pokazalo je da su scene u Srbiji, Makedoniji i Crnoj Gori nejednake snage - scena u Srbiji je najrazvijenija (i u pogledu brojnosti, raznovrsnosti organizacija i programa i u pogledu razvijenosti kapaciteta), dok na nezavisnoj kulturnoj sceni u Crnoj Gori deluje svega nekoliko organizacija razvijenih kapaciteta. Klaster analiza koja je uključivala podatke o svih pet tipova kapaciteta u Srbiji je izdvojila $15 \%$ organizacija izrazito dobro razvijenih kapaciteta (treći klaster na grafikonu 2) i još $27 \%$ organizacija sa značajnim ljudskim, tehničkim, finansijskim, 


\section{PREDRAG CVETIČANIN}

menadžerskim i socijalnim resursima (četvrti klaster). U slučaju $43 \%$ organizacija potrebne su aktivnosti jačanja nekog od kapaciteta (drugi klaster), dok se 15\% nalazi u organizacionom povoju (prvi klaster).

Grafikon 2

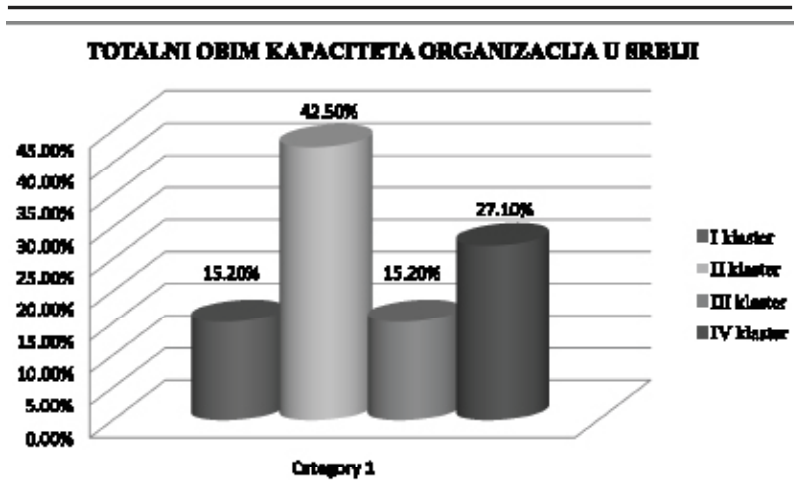

U Makedoniji nema organizacija sa izuzetno dobro razvijenim resursima, dok $24 \%$ organizacija ima dobro razvijene resurse (drugi klaster). U slučaju 52\% organizacija potrebni su programi jačanja kapaciteta (prvi klaster), dok još $24 \%$ (treći klaster) ima nerazvijene resurse.

Grafikon 3

TOTALNI GRIM KAPACITETA ORGANTZACUAU MAKTDONIII

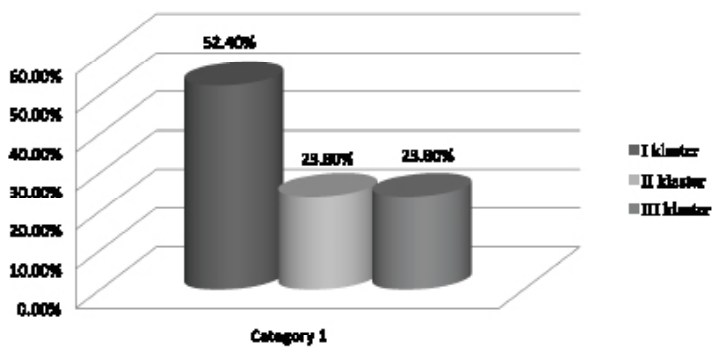

U Crnoj Gori pak samo jedna organizacija (treći klaster) ima razvijeno svih pet tipova kapaciteta, 35\% organizacija bi trebalo da poboljša svoje kapacitete (prvi klaster), dok se čak $57 \%$ (drugi klaster) organizacija nalazi u opasnosti da u promenjenim okolnostima, sa daljim smanji-

vanjem dostupnih fondova, počne da nestaje. 


\section{PREDRAG CVETIČANIN}

Grafikon 4

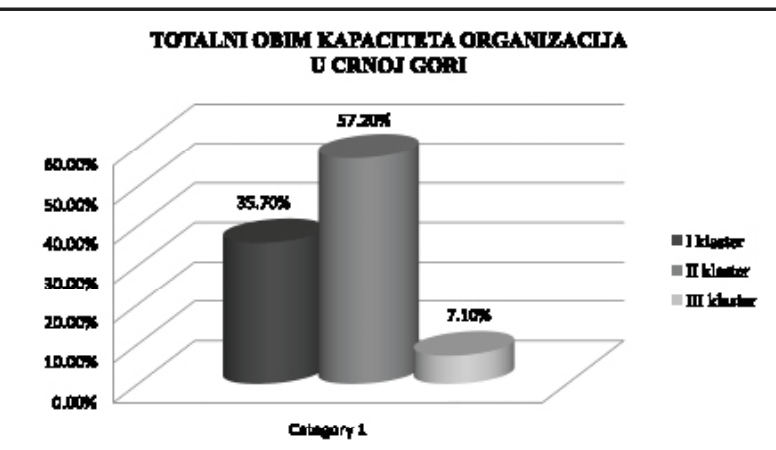

Umesto zaključka

Tri razloga su nas navela da započnemo ovo istraživanje. $\mathrm{S}$ jedne strane radi se o nepoznatoj i neistraživanoj oblasti. ${ }^{31} \mathrm{~S}$ druge strane, nedostatak podataka onemogućavao je formulisanje racionalne kulturne politike, kako od strane samih aktera nezavisne kulturne scene, tako i sa strane Ministarstva kulture, lokalnih uprava za kulturu i međunarodnih donatora. Treći razlog je vezan za trenutak u kome je istraživanje realizovano. Naše je uverenje bilo (onda kada je projekat koncipiran) da se nezavisna kulturna scena u Srbiji, Crnoj Gori i Makedoniji nalazi na prekretnici i da je vreme za promenu strategije delovanja. U suprotnom bi, s obzirom na promenjene okolnosti, ostajanje u stanju atomizovanosti i izolacije moglo u relativno kratkom perodu da „desetkuje“ scenu, ostavljajući na njoj samo najveće organizacije. ${ }^{32}$ Utoliko se može reći da smo ovim empirijskim istraživanjem težili da istovremeno pružimo iskustvenu osnovu za koncipiranje nove strategije delovanja nezavisne kulturne scene i za formulisanje (na empirijskim podacima bazirane) kulturne politike od strane Ministarstva kulture, gradskih uprava za kulturu i međunarodnih donatora u ovoj oblasti.

Neka nam na kraju ovog teksta bude dozvoljeno da samo skiciramo argument zašto smatramo da je nezavisna kulturna scena u Srbiji, Crnoj Gori i Makedoniji (i drugim sličnim državama u regionu), kao ,anomalija“ u kultur-

31 Tokom istraživanja postalo nam je jasno da ne samo što istraživači koji se bave kulturnom politikom imaju malo podataka o akterima sa nezavisne kulturne scene u Srbiji, Crnoj Gori i Makedoniji, nego i da sami učesnici ne znaju čak ni ko sve scenu čini (izvan vlastitih gradova).

32 Rad na istraživanju je ovo uverenje samo dodatno ojačao. 


\section{PREDRAG CVETIČANIN}

nom sistemu, važna za razvoj kulturne (i druge) politike u njima.

Tranzicija u zemljama regiona i njihova demokratska konsolidacija nisu, bar do sada, proizveli priželjkivane rezultate. Jedan od neočekivanih rezultata, jeste mutacija partijske države u multipartijsku državu. Ukratko, svi mehanizmi kontrole nad državom, nad državnim novcem, nad državnim institucijama, nad zapošljavanjem u javnom/državnom sektoru ostali su isti, samo što sada kontrolu nad ovim resursima ne vrši jedna partija, nego nekoliko partija (koje trenutno čine političku koaliciju).

Kulturne ustanove, kao državne institucije, paradigmatski su primer efekata multi-partijske države. Rukovodeća mesta u njima i mogućnost zapošljavanja partijskih kadrova u ovim organizacijama predmet je podele „plena“ nakon parlamentarnih i lokalnih izbora. Formalno-pravno konkursi za direktore postoje, ali u praksi isključivo partijski ljudi bivaju izabrani. U slučaju poraza na izborima, rukovodioci kulturnih ustanova iz ,gubitničkih“ partija bivaju smenjeni, bez obzira na to kakvi su bili njihovi rezultati u rukovođenju ustanovom. Iz tog razloga, oni više energije troše na partijski rad i praćenje trenutnih odnosa u partijskim koalicijama, nego na menadžerske i programske aktivnosti. Poseban paradoks jeste da članovi kolektiva kulturnih ustanova, prilagođavajući se modelu funkcionisanja, često (osim na rečima) ne žele da njihov direktor bude neko izvan partijskih krugova, jer bi to u praksi značilo da su im zatvorena vrata za dopunske fondove (koji su neophodni za iole uspešno funkcionisanje kulturnih ustanova), a koji se obezbeđuju partijskim kanalima. Svaki novi mandat prati i novo zapošljavanje članova pobedničkih partija, čak i ukoliko je (nedavno), jedan broj ljudi otpušten kao „tehnološki višak“. Atmosfera u kolektivima prati politički izborni ciklus: novi direktor/direktorka bivaju euforično dočekani kao prilika da se isprave pogreške i zloupotrebe prethodnog rukovodstva; program koji oni predlažu najčešće predstavlja potpuni diskontinuitet sa onim što je do tada rađeno; ukoliko su promene koje žele da uvedu u funkcionisanje kolektiva suviše velike (i nisu praćene eksplicitnom političkom podrškom realnih centara moći), bivaju smenjeni još pre kraja mandata; a u slučaju da se prilagode ustaljenom (ne)radu u ustanovi, opstaju do kraja mandata, a da im pri tom, nekoliko meseci pred izbore, kolektiv otkaže poslušnost (a sindikat $u$ organizaciji počne da ukazuje 


\section{PREDRAG CVETIČANIN}

na njihove „pogreške i zloupotrebe“). A direktori sami, neposredno pre nego što će biti smenjeni, u javnosti lamentiraju nad činjenicom da su smenjeni političkim putem (zaboravljajući da su na ta mesta takođe postavljeni političkim putem).

Dobro bi bilo kada bi ova kratka kozerija (zalutala u stručnu raspravu o vaninstitucionalnim akterima kulturne politike), bila samo to. Ali ona suviše liči na stvarnost koju pokušavamo da objasnimo i razumemo.

Ključni nedostatak nezavisne kulturne scene - to što se one nalaze izvan institucionalnog sistema kulture - predstavlja osnov za njen značaj u sistemu kulturne politike. Verovatno da je jedini razlog zašto taj prostor "slobode“ izvan neposredne partijske kontrole ${ }^{33}$ postoji, to što akteri multi-partijske države smatraju da su resursi koji se tu nalaze suviše maleni i da ne zaslužuju pažnju. A činjenica da se nalaze izvan neposredne političke kontrole, ujedno objašnjava zbunjenost kod donosilaca odluka na nacionalnom i lokalnom nivou, kada akteri nezavisne kulturne scene zahtevaju da budu priznati kao ravnopravni učesnici u kreiranju kulturne politike. A posebno kada polažu pravo na to da, pošto doprinose ostvarenju javnog interesa u kulturi, budu finansirani budžetskim novcem (kroz instituciju konkursa ili bilo kako drugačije). Ukoliko bi u toj borbi (pomognuti svima onima koji žele racionalnije uređenje kulturne sfere) uspeli da dokažu opravdanost svojih zahteva za učešće u kreiranju kulturne politike i pravo na finansiranje aktivnosti iz budžeta, akteri nezavisne kulturne scene, ta ,anomalija“ u odnosu na kulturni sistem kakav postoji, mogli bi postati primer uspešnog „oslobađanja“"i za druge segmente društva.

\section{LITERATURA:}

Cvetičanin P., Ispitivanje kapaciteta NVO u južnoj i istočnoj Srbiji, OGI, Niš, 2005.

Dragićević-Šešić M. i Stojković B., Kultura - menadžment, animacija, marketing, Clio, Beograd 1996.

Dragićević-ŠSešić M. i Dragojević S., Menadžment umetnosti u turbulentnim okolnostima, Clio, Beograd 2005.

Đukić-Dojčinović V., Tranzicione kulturne politike - konfuzije $i$ dileme, Zadužbina Andrejević, Beograd 2003.

Đukić V., Država i kultura: studije savremene kulturne politike, Institut za pozorište, film, radio i televiziju, Beograd 2010.

33 Naravno, ovu slobodu ne treba idealizovati. Odustvo neposredne partijske kontrole ne znači odsustvo političkih i ekonomskih uticaja i prepreka. Kako reče jedan od intervjuisanih u Crnoj Gori: „Najveći problem je nezavisnost - jer u Crnoj Gori teško čovek može biti nezavisan. Ako nije ni sa kim, onda je protiv svakoga“. 


\section{PREDRAG CVETIČANIN}

Pehn G., Networking Culture. The Role of European Cultural Networks, Council of Europe Publishing, Strasbourg 2002.

Višnjić E., Kulturne politike odozdo, Policies for Culture, Amsterdam-Bucharest-Zagreb 2008.

\section{Predrag Cvetičanin}

Center of Empirical Studies of South-European Cultures

\section{NON-INSTITUTIONAL AGENTS OF CULTURAL POLICY IN SERBIA, MONTENEGRO AND \\ MACEDONIA}

This paper presents the results of a study which investigated cultural policy partakers active outside the system of public/ state cultural institutions in Serbia, Montenegro and Macedonia (non-governmental organizations dealing with culture, independent cultural associations, artists associations, informal art groups, non-profit cultural clubs, etc). Total of 112 independent cultural scene partakers participated in the study -71 in Serbia, 22 in Macedonia and 19 in Montenegro. The analysis relied on a combination of qualitative and quantitative methods: a survey intended primarily to gauge five groups of capacities of the organizations surveyed (human, technical, financial, managerial and social) and, on the other hand, semi-structured inter-

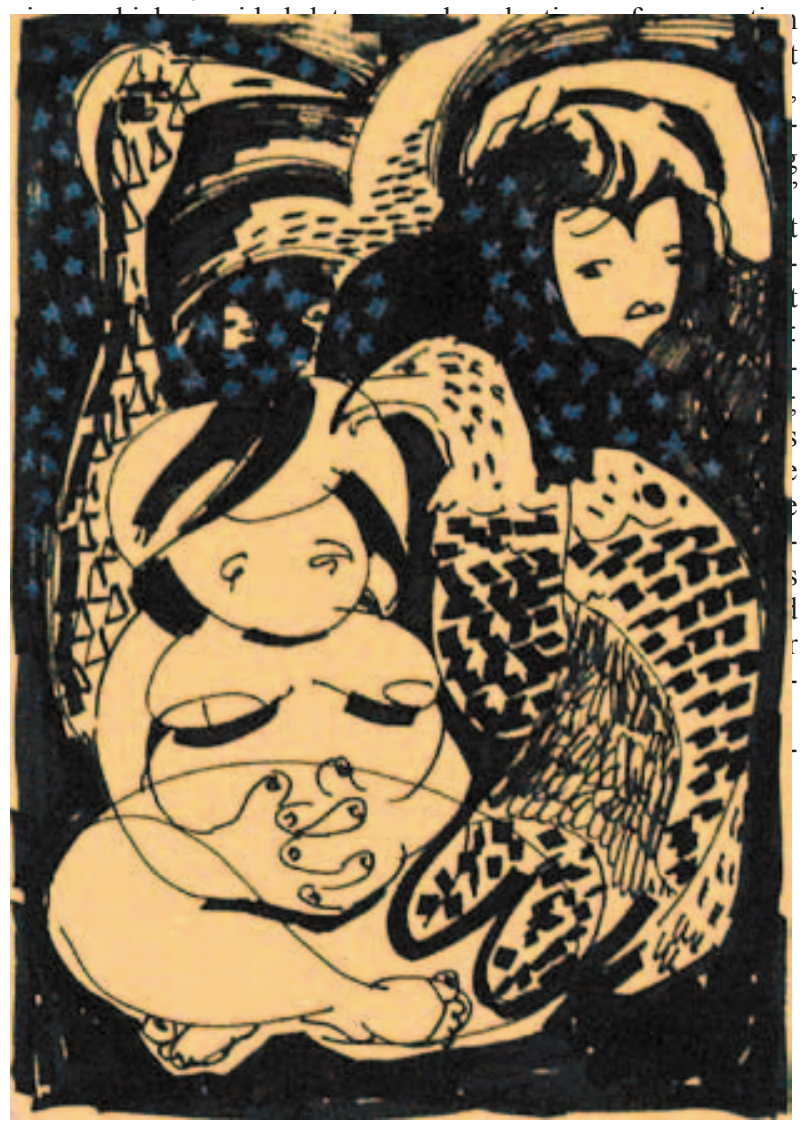

